\title{
Strategizing the for-profit city: The state, developers, and urban production in Mega Manila
}

EPA: Economy and Space 2020, Vol. 52(2) 403-422

(C) The Author(s) 2019 Article reuse guidelines: sagepub.com/journals-permissions DOI: 10.1 I77/03085 I8X19840365 journals.sagepub.com/home/epn @SAGE

\author{
Morgan Mouton (D) \\ University of Calgary, Canada
}

\section{Gavin Shatkin}

Northeastern University, Boston, USA

\begin{abstract}
This article explores the evolving role of real estate developers in the wider metropolitan region of Manila, the Philippines. We argue that, given the relational nature of these actors, they are a relevant object of analysis for the formulation of "mid-level" theories that take into account both global, macroeconomic trends and local, history-dependent contingencies.

As we consider developers' activities and interactions with a wide range of public and private actors, we retrace their gradual empowerment since the beginning of the postcolonial period. As a handful of powerful land-owning families created real estate development companies, urban production quickly became dominated by a strong oligarchy capable of steering urban development outside the realm of public decision-making. Philippine developers subsequently strengthened their capacity by stepping into infrastructure provision, seemingly expanding their autonomy further.

More recently, however, we argue that while the role of private sector actors in shaping urban and regional trajectories has scaled up, their activities have been tethered more strongly to a state-sponsored vision of change. Both by reorienting public-private partnerships (PPP) toward its regional plans, and by initiating new forms of public-private partnerships that give it more control, the state is attempting to harness the activity of developers. We characterize this shift as a move from the "privatization of planning" to the "planning of privatization" of urban space.
\end{abstract}

\section{Keywords}

Real estate developers, Mega Manila, urban production, infrastructure, assemblage

\footnotetext{
Corresponding author:

Morgan Mouton, University of Calgary, Teaching, Research and Wellness Building (3rd floor), 3280 Hospital Drive NW, Calgary, AB, Canada T2N 4Z6.

Email: morgan.mouton@ucalgary.ca
} 


\section{Introduction}

This theme issue seeks to theorize the role of developers in the production of urban space by focusing attention on their relational role in bringing together the various actors and elements through which urban space is produced. It asks what role developers play in assembling material elements (land, infrastructure), actors (state actors, architects, consumers), and finance in urban development processes, and what implications their role has for the spatial change that results. In this study of Metro Manila, we argue that addressing this question requires an understanding of the contingent historical circumstances in which the developer operates. What sources of social, economic, and political power enable developers to play the role that they do? Through what historical process of change has their role taken shape? In the context of these local histories of urban transformation, what kinds of relationships are they creating, and toward what objective of urban change?

With this contribution, we seek to focus on one particular aspect of developers' work: their relationship with the state. In the case of Metro Manila, a rich literature has portrayed the Philippines as a case of a "weak state" that is beholden to corporate interests (e.g. Bello, 2005; Hutchcroft and Rocamora, 2003; Kang, 2002; McCoy, 2009). Indeed, developers have historically played a relatively prominent role in urban development dating back to the beginning of the postcolonial era at the end of the 1940s, and the period since the late 1980s has seen a dramatic increase in the scales at which they operate. As Shatkin (2008) has argued, the 1980s and 1990s witnessed an effort by the largest developers to reshape trajectories of urban and regional change to their commercial advantage by growing large, integrated developments across the metropolitan region, and by diversifying into transportation and other forms of infrastructure provision to link these projects and ensure adequate service provision. Shatkin characterized this shift as constituting a "privatization of planning," as the state increasingly acceded to a more pronounced role for developers in visioning and realizing urban futures, and developers came to play a role in assembling corporate actors and elements of the state in pursuit of a coordinated approach to urban and regional development.

Consequently, it is tempting to summarize the Philippine context as one combining a "weak state" and "strong private actors." In this paper, however, we seek to depart from this over-simplification and interrogate the relationship between developers and the state in a way that provides a more nuanced interpretation, focusing rather on the array of strategies that both parties use to advance their agendas.

In this paper, we will argue that the relational work of developers has continued to shift. Building upon extensive field research conducted by both co-authors over a number of years, which we supplemented by an analysis of administrative documents, we will show that the Philippine national government has recently attempted to reassert itself in assembling the elements of urban development, by formulating aggressive new plans for the development of a "Mega Manila" metropolitan region, and advancing this vision through the assertive pursuit of public-private partnerships in megaproject infrastructure and planned urban spaces. This trend has seen developers respond by entering yet more deeply into the realm of infrastructure provision. It has also seen other major conglomerates, notably the San Miguel Corporation (SMC), diversify into urban development and infrastructure provision, lured by the profits to be had from state-sponsored megaproject deals. Hence, the role of private sector actors in shaping urban and regional trajectories of change has scaled up, yet this role has been tethered more strongly to a state-sponsored vision of change. We characterize this shift as a move from the "privatization of planning" to the "planning of privatization" of urban space. These transformations have emerged in 
response to several interrelated dynamics: (a) the changing state-corporate relationship in the evolution of the postcolonial Philippine state; (b) the shifting interests of global capital and its resultant incursion into the Philippine political economy; (c) changes in globally circulating models of regional development; and (d) the path-dependent changes that the Philippine state has undergone. The relational role of developers has therefore shifted with changes linked both to the particularities of the Philippine political economy and changes in global dynamics of political power, finance, and trade and investment.

This observation of the interplay between universal and context-specific forces leads to a larger theoretical and methodological argument - that developers hold significant promise as a unit of analysis in studies that employ a conjunctural mode of analysis. The work of developers is informed and constrained both by the global circulation of finance and models of urbanism, and by myriad local institutions: (a) governance regimes; (b) corporate economies; (c) property rights regimes; and (d) patterns of land ownership to name a few. Because they must navigate both of these sets of constraints, they represent an important juncture at which universalizing global forces and contingent local contextual factors meet. This paper will first briefly discuss a conjunctural mode of analyzing the relational role of developers, before discussing the shifting role of Metro Manila developers in the postcolonial period.

\section{A conjunctural approach to understanding the relational work of developers}

The past several years have seen persuasive calls from urban scholars for the further development of conjunctural approaches to urban analysis, as a response to the seeming polarization of perspectives in urban theory regarding the relative role of universal structures of power versus local contingency and agency in shaping urban change. Leitner and Sheppard (2015: 229) summarize this debate as follows:

On the one hand are scholars, attentive to recent articulations of urbanization and globalization,
who propose all-embracing concepts. [...] For all these scholars, the underlying presumption is
that an understanding of urbanization as it has occurred in the Euro-American realm is also
applicable across the postcolony; that the specificities of cities of the postcolony simply reflect
the local context, and do not disrupt core theoretical claims and urban policy implications.
On the other hand is an emergent cluster of scholarship seeking to develop new theories to
account for the specificities of urbanization across the postcolony, often dubbed postcolonial
urban theory.

In other words, theorists of varied traditions of structuralist political economy privilege the task of identifying and analyzing universal phenomena that structure the production of urban space in capitalist societies. These may be transcalar forces such as flows of financial capital or the imposition of neoliberal orders through international rule regimes (Brenner and Schmid, 2015), or purportedly universal "laws" of urban production such as the "urban land nexus" (Scott and Storper, 2015). While they do not deny the need for an understanding of context and specificity, scholars writing from such a perspective warn that too strong a focus on particularity may lead scholars to disregard the role of structuring forces to the extent of compromising the robustness of resulting theories (Brenner et al., 2011). For postcolonial theorists, on the other hand, this privileging of structure risks perpetuating a myopic approach to theory building that simply reproduces insights derived from 
Euro-American experiences (Robinson and Roy, 2016) Important new theoretical breakthroughs are to be gained, they argue, from building new theory from a grounded examination of the cities of the Global South.

Theorists of a conjunctural approach argue for a need to move beyond this dualistic debate, and instead to analyze the intersections of external forces and deeply rooted contextual forces. In a conjunctural view, cities are products both of "spatio-historical specificities as well as interconnections and mutually constitutive processes," thereby reflecting interrelations and contestations between more globalized and more localized sources of agency (Hart, 2016: 3). All cities must therefore be understood to have agency, acting as "sites in the production of global processes in specific spatio-historical conjunctures, rather than as just recipients of them" (Hart, 2016: 3). Analyzing cities through a conjunctural approach therefore requires interpreting these spatio-historical conjunctures by moving back and forth between a deep understanding of city-specific histories of social, economic and political change, and their interrelation with larger structural forces. Peck (2017: 10) has further argued that such an approach entails the production of "mid-level theoretical formulations"- theories suitable for testing across multiple sites that seek systematically to understand the interplay between grounded contextual factors and the influence of global interconnections.

We argue that developers are an excellent object of study to develop such "mid-level theoretical formulations." While they act as conduits for and to some extent as agents of global financial actors and globally circulating models of urbanism, developers are also deeply embedded in regimes of governance and politics, property rights, land ownership, and historically embedded urban social and spatial relations. They are also constrained by dynamics of landscape, ecology, and hydrology. In their relational role, therefore, developers emerge as a point of articulation between global forces and conditions in localities, as actors that assemble land, finance, institutions of governance, and urban design to restructure the relationship between the built environment, socio-spatial relations, urban ecologies, and urban political power. Hence an analysis of the machinations and travails of developers and the plans they put forth can provide insights into the questions of generalizability and specificity that lie at the heart of a conjunctural approach to urban analysis. The emergent relational role of the developer, and the critical role of this figure in processes of assemblage, raises important questions: What institutional, legal, political, and economic transformations have led to their emergence as central actors in diverse contexts? From what sources of power do they derive their relational role? What kind of relationship between state and capital do they embody, and how does this differ contextually?

While there are surprisingly few studies that focus on the role of developers (in comparison to the preponderance of studies which focus on specific projects or dynamics of real estate markets), recent years have witnessed a growth in this area (Fainstein, 2001; Harms, 2016; Leaf, 2015; Rouanet and Halbert, 2016; Sajor, 2005; Searle, 2014). When read alongside associated literatures on urban megaproject development, and transnational practices in architecture and urban design, two fundamental insights regarding the relational role of developers emerge. The first is that developers tend to be products of the political economy of state power that produces them. Indeed, where it has emerged to prominence relatively recently, the "real estate sector" as it currently exists is often to a significant degree a deliberate product of the application of state power in contexts in which certain state actors perceive an interest in urban transformations that can be realized through the commodification of urban space. State actors encourage and enable the formation of real estate sectors through regulatory change, political reform, and strategic partnership. Developers 
emerge as self-interested actors with visions for urban change, who nonetheless are politically connected and aware that they are not entirely autonomous of the state.

One quintessential case of this development of the real estate sector is Jakarta, where state-owned enterprises, construction companies, and mason builders dominated urban development through the 1970s. While private corporate developers engaged in modest residential and office construction in Jakarta in the early 1970s, they exploded onto the scene as central actors shaping urban form in the 1980s, when the first of a wave of massive privately developed new town projects broke ground in peri-urban regions across the Jakarta Metropolitan Area (Winarso, 2000). The regulatory mechanism that enabled this emergence was the transformation of the ijin lokasi (location permit) into a tool to transfer rights over lands held by the state and customary users to corporations for large-scale development (Leaf, 1993). The bulk of the permits that were issued in the 1980s and 1990s went to large corporations controlled by families that enjoyed close relationships with the authoritarian Suharto regime, and that also often owned major banks, cement companies, and construction companies among their extensive holdings (Lorrain, 2016; Winarso and Firman, 2002). Hence "private developers" emerged as major urban power brokers embodying many of the elements that are assembled in urban development (land, finance, construction materials, architects, and urban designers).

In other settings, the role of state actors in the formation of real estate sectors differs. In China, where land and real estate markets were constituted in the 1980s when the Chinese Communist Party began experiments with the leasing of state land, developers consist of two groups: Primary developers, which are public agencies empowered by law to clear and service land and transfer it for for-profit development, and secondary developers, which are either state or private sector entities that acquire land and develop real estate products (Hsing, 2010). "Private" and "public" actors are deeply entangled in these processes, and take myriad hybrid forms (e.g. state-owned corporations that are partially publicly listed) (Rithmire, 2015). In general, though, state actors continue to dominate the development process, and developers are either state entities or operate in an environment which is powerfully circumscribed by the power of Party officials over the supply of land and finance. A broadly similar dynamic is at play in Singapore, where the state largely controls the supply of developable land, and owns a substantial equity stake in the largest corporate developers (Shatkin, 2014). In India, corporate real estate developers have frequently emerged from construction companies that had previously built on a contract basis for "government clients, industries, cooperative housing societies, or individual landowners" under the regime of state socialist urban development that prevailed until the 1980s (Searle, 2010: 28). Deregulation of urban development and the financial sector and emergent municipal efforts to transfer land for private sector development have given rise to the growth of large real estate developers. In India's decentered political context, these actors are relatively autonomous of the state, although they have often lobbied intensely and formed statecorporate coalitions for infrastructure investment, regulatory relaxation, and political assistance in land clearance and relocation of communities.

A second important theme that emerges from the comparative literature on developers is that, because they emerge through different relationships with the state, and in response to particular contexts of land, regulation, finance, and corporate interest, developers play very different roles in different contexts. In prevalent theories of urban political economy, particularly theories of urban regimes and entrepreneurial urban politics that originated in the USA and the UK, developers are largely understood as autonomous corporate actors who join other economic interests in seeking to influence urban policy, but whose scale of operation and extent of agency is circumscribed by the state's regulatory role. Hence the power 
of developers is shaped by the context of electoral politics and competition for influence with civil society and with other factions of capital (Fainstein, 1995). Municipal governments also may play a role in ensuring that the actions of real estate developers conform to broader goals of capital accumulation, and that their tendency toward cyclical overbuilding is reined in, by providing oversight and regulation of the various elements in the real estate assemblage, particularly land and finance (Fainstein, 2001; Logan and Molotch, 1987). Yet, as the examples cited above reveal, the relationship between the state and real estate developers, and the state's interest in and powers over real estate actors, varies widely. Some of these configurations may lead to conflicts of interests between state roles in urban development and the personal interests of developers and individual members of the state.

In the account that follows, we seek to trace the changing relational role of developers in Metro Manila. We will argue that recent years have seen a distinct shift in the relational role of developers, from a situation in which they have acted with relative autonomy and agency in shaping urban space, to one in which they have become more reactive in the face of the growing assertiveness of state planning authority.

\section{The evolving relationship between real estate developers and the Philippine state}

In May 2014, the head of the international sales division of Ayala Land, one of the oldest and most important real estate developers in the country, claimed in an interview that part of his company's success was due to the absence of strong public oversight of urban development:

The fact that there is nobody in the Philippines who regulates urban planning has been great for Ayala Land, because we are probably the only company there that has the scale financially to take on large plots of land.... By developing big tracts of land, we become the government; we control and manage everything. We are the mayors and the governors of the communities that we develop and we do not relinquish this responsibility to the government... But because we develop all the roads, water and sewer systems, and provide infrastructure for power, we manage security, we do garbage collection, we paint every pedestrian crossing and change every light bulb in the streets - the effect of that is how property prices have moved. ${ }^{1}$

One can indeed observe that real estate developers have acquired an unusual level of autonomy, and that they have played a strong role in shaping Metro Manila and its surrounding region. Since the 1990s, Ayala Land's role has in fact extended beyond that described in the above quote, as Ayala has become a major actor in public transportation.

Taking advantage of a strong demand for both residential and office premises, ${ }^{2}$ a small number of large real estate developers quickly came to dominate urban production. These companies are usually part of family-owned, diversified conglomerates whose weight in the Philippine economy is substantial (Table 1). The list includes the old landed elite whose activities can be traced back to the Spanish colonial era (Ayala Land, SMC), but also a number of newer players that emerged in the 1970s and 1980s, most of them familyowned businesses of Chinese descent: SM Investments, JG Summit, Aboitiz Group, DMCI Holdings, Filinvest Development Corp, and Megaworld Corp.

Yet we argue that the role of developers in Metro Manila has not remained a simple story of a weak state reliant on and beholden to corporate developers. Rather, it has seen moments of significant change in response to transformations in the political economy of 


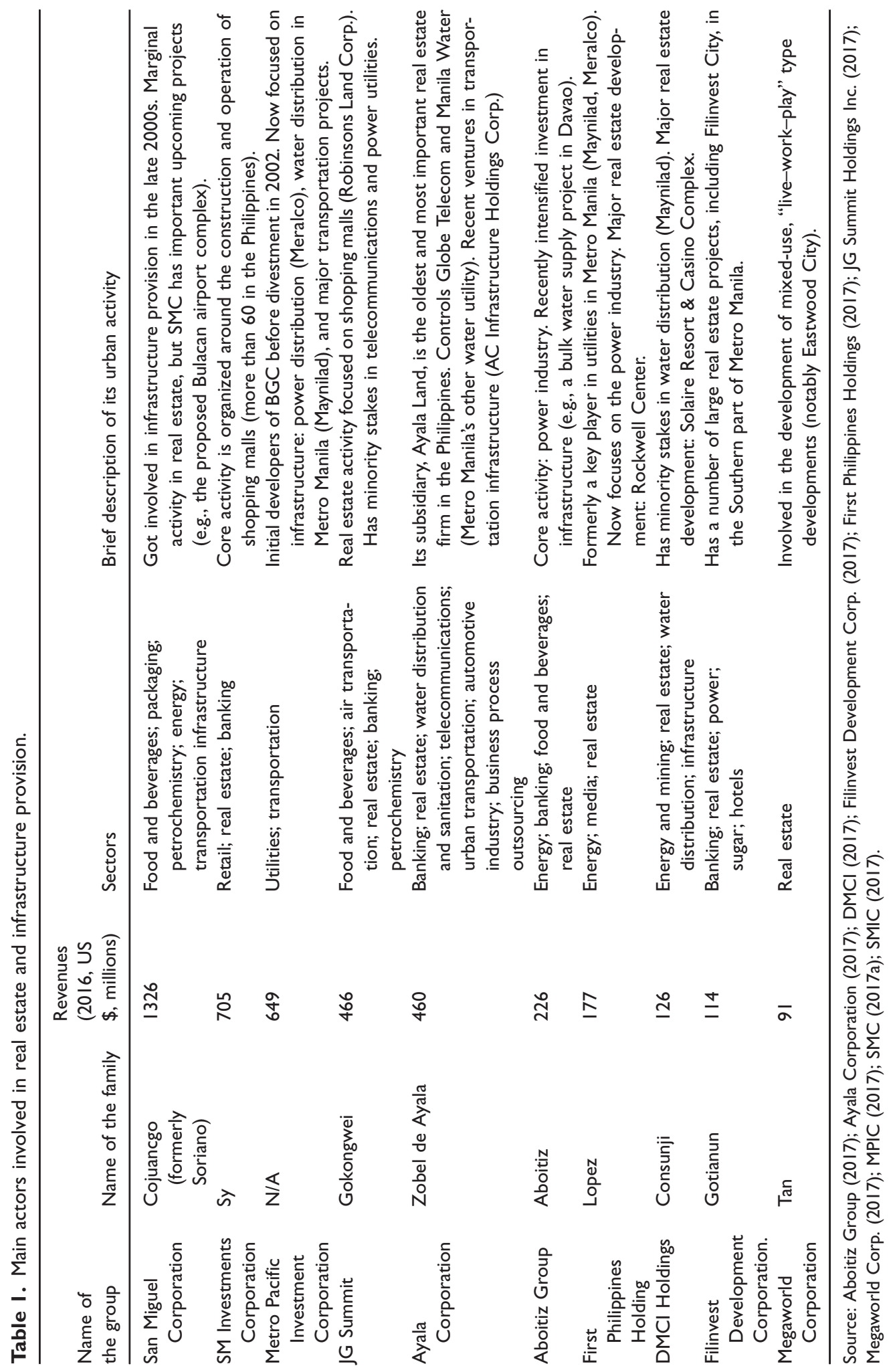


the Philippine state. These changes have occurred with shifts in electoral politics and in the Philippines' relations with circuits of international finance and investment. This section will discuss the historical forces that led to the strong role of developers, while the next section will discuss the more recent shift toward a reassertion of state planning in the expansion of the extended Metro Manila region, which has drawn on the financial and technical capacity of major developers and the corporate sector.

The unusually powerful and autonomous role of developers in shaping Metro Manila and its extended region has its roots in the immediate postcolonial period, when a small number of land-owning families came to dominate national politics. As noted by van den Muijzenberg and van Naerssen (2005), in Manila and its surrounding region the large agricultural estates owned by elite families (the Legardas, Tuazons, Aranetas, and others) have been extensively converted to densely populated areas, in a postwar period that witnessed dramatic demographic growth. While most estates were simply divided and sold or leased as such - what van den Muijzenberg and van Naerssen characterize as practices of "rent capitalism"- other families engaged in processes of land valorization.

In this regard, the pioneering and well-documented case of New Makati stands out as an important early experiment with large-scale privatized urbanism (Caoili, 1989; Garrido, 2013). In Makati the Ayala family turned its large estate, located at what was to emerge as the center of Metro Manila and its surrounding conurbation, into a carefully planned and fully serviced "self-contained community," which comprised residential, commercial, and industrial districts. By the 1960s this planned development had established itself as Metro Manila's central business district (CBD), and while no longer unchallenged it still holds the highest concentration of corporate headquarters in the country. The Ayalas developed a master plan that meticulously organized zoning, density, and traffic management, but also handled infrastructure provision, while delegating basic services (garbage collection, street lighting, maintenance, security) to residents' associations (Garrido, 2013: 172). The rise of Makati transformed the metropolitan area dramatically, changing its center of gravity, influencing the surrounding urban fabric and structuring the public transportation in surrounding cities. All of this was the result of decisions taken by a single corporation, for the most part outside of the realm of public decision-making.

The 1970s and 1980s did witness significant efforts by the state to reassert its control over land under the authoritarian regime of Ferdinand Marcos (1965-1986). Such an attempt materialized institutionally with the creation of the Metro Manila Commission (MMC), headed by Marcos's wife, Imelda. This new metropolitan organization reduced municipalities' powers substantially, by taking over their prerogatives on such diverse issues as transportation, waste collection and management, housing, environmental management, and public health. More generally, the MMC was in charge of developing a master plan for the capital region. It centralized urban planning by bypassing municipalities, and therefore mayors, who were potential political opponents (Caoili, 1989). Spatially, this episode of state strengthening materialized with the construction of large public-led projects, which were designed as the embodiment of the Marcoses' modernist visions of a new Philippine society (Shatkin, 2005).

The period after the fall of Marcos in 1986, however, saw a powerful reassertion of the role of large developers, notably Ayala Land, in shaping urban space. At the same time, state efforts to plan for Metro Manila's development were shaped and constrained by the powerful influence of international rule regimes, and specifically its adoption of measures of fiscal austerity intended to placate the International Monetary Fund and ensure that the Philippines could service its debt (Bello, 2005; Bello et al., 2014). In this context, Metro Manila shifted back to a more decentralized functioning. The 1992 Urban Development and 
Housing Act considerably weakened the metropolitan authority (now designated as the Metro Manila Development Authority [MMDA]), leaving the organization with fewer prerogatives and no resources - institutional or financial - to handle them (Laquian et al., 2002). As a consequence, coordination among municipalities has been poor, leaving room to maneuver for real estate developers to shape the metropolitan region according to their own, profit-driven agenda.

Meanwhile, pressure from the Bretton Woods Institutions led the Philippines to adopt a "public-private partnership turn" in the 1980s, which has had important implications for Metro Manila's planning agenda. This decision was endorsed after Marcos's destitution, and the process accelerated during the term of president Fidel Ramos (1992-1998), who placed privatization at the top of his agenda (Ana, 1998). Public assets divestment then reached its peak: Philippine Airlines in 1992, Oriental Petroleum and Mining Company, Paper Industry Corporation of the Philippines, Philippine National Bank, National Steel Corporation in 1994, and most of the telecommunication infrastructure in 1995 (see Bello, 2005; Riedinger, 1995).

The privatization of electricity generation in the context of a severe power crisis in the course of the 1990s, followed by water distribution in 1997, were publicized as major successes by the Ramos administration-despite massive tariff hikes that would occur later in both sectors (see IBON, 2005; Mouton, 2015) - and provided a strong argument for the proponents of privatization at the time. The recourse to PPP has not been challenged by any administration since.

With extensive input from international organizations (the World Bank, the Asian Development Bank) and national ones - notably the Philippine Institute for Development Studies - new guidelines were drafted in order to regulate these new modalities of infrastructure production (see Llanto, 2004, 2010). The most important legal tool in place is the Build-Operate-Transfer (BOT) law of 1994 (R.A. 7718), which has been amended several times since its promulgation. New institutions were also created, notably the Public-Private Partnerships Center (PPP Center) of the Philippines, created in 2010 as an administration answering directly to the National Economic and Development Authority (NEDA), and designed to provide assistance to any public administration willing to engage in PPP.

While the policy push toward PPP has fostered opportunities for corporate actors in infrastructure provision, the spatial expansion of Metro Manila and its extended region has opened opportunities for the expansion of the "Makati model" of privatized planning of urban space. A key moment here was the influx of manufacturing investment from Japan following the increased valuation of the Japanese yen with the signing of the 1985 Plaza Accord, which led to a wave of Japanese offshoring. Keen to open up peri-urban spaces for Japanese manufacturing investment, the Japanese International Cooperation Agency (JICA) formulated a masterplan for CALABARZON, a term for the urbanizing provinces of Cavite, Laguna, Batangas, Rizal, and Quezon, which encircle Metro Manila. JICA provided more than US\$1 billion in aid in the decade that ensued to support infrastructure investment in this extended and rapidly urbanizing region (Kelly, 2013). The explosion of manufacturing investment that coincided with this investment fostered new opportunities for developers to build export-processing zones and new large integrated residential and commercial districts across Metro Manila and into the surrounding provinces. Such projects often took form through the opportunistic privatization of large landholdings of elite agricultural families (as in the cases of Ayala Alabang, Ayala South, and the Laguna Technopark in the southern portion of the metropolitan region), and increasingly from the mid-1990s on through the transfer of public landholdings and the formation of PPP on public land - as in the cases of Bonifacio Global City and Rockwell Center (Shatkin, 
2008). It is this period that Shatkin (2008) characterizes as one of privatized planning, in which developers took center-stage. With the shift toward a PPP approach, Ayala Land in particular also began to expand into infrastructure provision beyond the scale of the individual projects, through investments in metropolitan and regional transportation infrastructure and water provision (through its subsidiary Manila Water) aimed at ensuring adequate services and accessibility of their developments.

In sum, the 1990s saw developers emerge as powerful actors in the political economy of metropolitan expansion, "conceiv[ing] of corporate visions, then conven[ing] public sector entities (a hodgepodge of local governments, national agencies, and special-purpose agencies) to pursue their own objectives of urban transformation for corporate profit" (Shatkin, 2008: 388). Their central role emerged from a combination of factors - a period of financial weakness and transition of the Philippine state, the international transfer of ideals of privatization, the opportunities for linked infrastructure and land development emerging from rapid urbanization and industrial expansion, and the availability of large landholdings at the urban fringe that were controlled or could be acquired by large corporate developers.

\section{From the privatization of planning to the planning of privatization: The Philippine state's infrastructure push}

Thus far, we have drawn a portrait of a withdrawn state that plays a relatively weak role in the sphere of urban production. However, if public authorities tend to rely upon the private sector to build and operate infrastructure, does it mean that they have given up on steering urban development altogether? Here, we would like to formulate the hypothesis that the previously described "privatization of planning" is being challenged by the Philippine state. However, we argue that this process does not materialize with a show of strength by the state, with what would be an echo of the Marcos era. Instead, what we observe is an attempt from the state to harness the power of private firms. We characterize this as a shift from the "privatization of planning" to the "planning of privatization." Following a discussion of the origins of this shift, we discuss two initiatives that reflect this assertion of a stronger state role - the formulation of the "Mega Manila Dream Plan" for an infrastructure-driven restructuring of the extended metropolitan region surrounding Metro Manila, and the growing role of the Bases Conversion Development Authority as a government partner in urban real estate megaproject schemes.

\section{Characterizing the shift}

The Philippine state has limited room to maneuver when it comes to planning, since it holds very little land. In the past, its attempts at implementing masterplans were routinely crippled by private land owners: Soon after the plans were made public, speculative practices would render the acquisition of land impossible for the state (Alcazaren, 2013). Even when Marcos sought to reaffirm the state's grip on urban development, it is notable that a sizeable portion of his projects was developed on land that had to be reclaimed from the sea, by the Manila Bay. Orchestrating urbanization in the wider metropolitan region without cooperation with the private sector therefore appeared difficult for the state, and PPP unsurprisingly emerged as the preferred way to organize this cooperation. As argued previously, however, these mechanisms had led to corporate-driven visions of development in Manila (Shatkin, 2008) and to uncoordinated provision of transportation and basic infrastructure throughout the national capital region in the 1990s (Corpuz, 2000) and in the early 20th century. What has changed? 
We argue that the Philippine state's attempt at steering urban development has taken the form of a massive infrastructural push. In other words, the difference between the current period and the 1990s primarily resides in the quantity of PPP, and this volume allows for a coordination that public authorities could not achieve when infrastructure projects were one-off endeavors. In order for this strategy to come to fruition, though, two conditions had to be met: The environment had to be favorable on both sides of the PPP.

On the public side, the 2010 s were a period of relative political and fiscal stability. After years of corruption scandals during the presidencies of Joseph Estrada (1998-2001) and Gloria Macapagal Arroyo (2001-2010), political institutions were able to consolidate during the relatively scandal-free term of President Benigno Aquino (2010-2016). President Aquino's term witnessed new initiatives in regional planning, while the recent election of Rodrigo Duterte has seen an effort to strongly reassert state power through a muscular brand of economic nationalism and populism. Recent years have also seen a steady decline in the Philippines' debt to GDP ratio, to 40.6\% in 2016 (Carballo, 2017). This strengthened fiscal situation, and projections of further declines in debt to GDP, have emboldened the Philippine government in its plans for infrastructural expansion. The matter was all the more pressing as infrastructural deficiency emerged as a major trope in Philippine national political discourse. Infrastructural deficiencies led to a series of politically controversial scandals in 2015, including major traffic woes in Metro Manila and problems with the MRT-3 metro system, issues of corruption at the national airport, and delays in the construction of the LRT-1 Cavite extension, a major infrastructure initiative to link central Metro Manila to the province of Cavite to the south (Teehankee, 2016). According to a study by the World Economic Forum, the country ranked last among major ASEAN economies in the quality of railroads, ports, airports, and telephone and mobile phone technology (Schuster et al., 2017).

The Philippine government had the means of opportunity to initiate a major infrastructural overhaul, with much of this effort centered in the economically important Metro Manila region. NEDA's medium-term development plan for 2017-2022 called for US\$168 billion in infrastructure investment during this period. These projects invest in different sectors of infrastructure (including water resources, sewerage and sanitation, flood management, and solid waste management), but the lion's share is in transportation projects. After 2016, the new administration further accelerated this movement: In 2017, President Duterte made infrastructure a central and very visible part of his agenda, launching an initiative plainly titled "Build-Build-Build" that essentially repackages existing plans and speeds up the timetable for their realization. The website for the program brands the infrastructure agenda as "Dutertenomics" and emphasizes a push for both speed and transparency in project implementation (Freedom of Information Philippines, 2017).

This aggressive infrastructural agenda was to be funded in large part through a dramatic increase in spending, from about $2.5 \%$ of GDP previously, to $5.3 \%$ in 2017 and up to $7.4 \%$ by 2022 (Schuster, 2017). It was also to be funded and implemented through the extensive use of PPP. Overall, 20 projects have already been approved, representing approximately \pm 750 billion (over US\$14 billion) in investment, while 55 are still in the NEDA "pipeline," pending approval (NEDA, n.d.). In total, while many of the projects' costs have yet to be determined, over \pm 1.5 trillion are budgeted (approximately US\$30 billion).

On the private side, these years witnessed a surge in investment and economic growth in Metro Manila and its surrounding region, and the prospects for further future increases linked to global economic change. Beginning in 2013 and 2014, China responded to slow growth in domestic markets and increased wage competition from other countries by stating its intention to move decisively toward becoming a capital exporter. By 2015 China's 
outward foreign direct investment (FDI) had in fact outstripped inward FDI, and China had moved rapidly up the charts to become the fourth largest investor in ASEAN. This surge in outward investment accompanied an assertive infrastructural agenda. In 2014 and 2015 China initiated a spate of mega, billion-dollar infrastructure projects across Central and Southeast Asia, and Africa, following the announcement of the "One Belt, One Road" initiative and the subsequent creation of the Asian Infrastructure Investment Bank and the Silk Road Infrastructure Fund (Ernst and Young, 2015).

The 2010s also saw a spike in the value of investment in real estate. Globally, commercial real estate investment, which had plunged from more than US\$1 trillion annually in 2007 to just above US\$200 billion in 2009, once again approached the trillion-dollar mark in 2015 (CBRE, 2017). ASEAN captured a share of this growth, seeing more than US\$19 billion in FDI flowing into real estate from 2014 to 2015, primarily from intra-ASEAN sources and from China and Hong Kong (ASEAN, 2016). Here, too, growing external investment in real estate from China portended a substantial potential increase from that source.

\section{Orchestrating corporate investment to realize a spatial vision: The Mega Manila Dream Plan}

The Philippine state's plans for a dramatic increase in infrastructure spending is part of a broader state agenda to reassert a role for central planning and achieve a vision of coordinated urban expansion. This effort was expressed by one prominent public official as an outcome of a new model of planning under President Duterte, although in fact this effort preceded the 2016 elections.

Unlike in the past, where projects of government have been quite independent of each other (project dito, project don, pero [a project here, a project there, but] they don't interrelate and they do not interconnect), the Duterte administration, under the leadership of our President, has made it a point that all projects are interrelated and interconnected, as they should be. ${ }^{3}$

Prominent on the spatial planning agenda has been a restructuring of Metro Manila and its surrounding conurbation. In 2014 NEDA and JICA released the Mega Manila Dream Plan, which sets forth a vision of an extended urban region that is projected to reach a population of 29 million by 2030 (NEDA, 2014). The plan seeks to develop a truly polycentric region, with major new urban centers anchored by Subic Bay Freeport and the Clark Freeport Zone in the north, and the Batangas International Port to the south. This is to be realized primarily through US\$60 billion in infrastructure investment that centers on major new transportation corridors that extend urban development to the north and south, and that integrate logistics and transport within these developing urban centers. Central elements include expressways, a $91 \mathrm{~km}$ north-south commuter rail, and a $75 \mathrm{~km}$ north-south subway. The plan also includes expansion of Subic Bay International Airport in the north, and relocation of Ninoy Aquino International Airport to an area south of Metro Manila.

These plans constitute an effort by the Philippine national state to position itself to engineer and orchestrate the transformation of "Mega Manila" as an economically dynamic mega-region. Yet they seek to do so in a manner that does not aim to go against the private forces that are already at work and that largely shape metropolitan development. Rather, through PPP, the plan seeks to exploit the technical expertise, financial capacity, and links to global circuits of knowledge about urban development that large developers embody. NEDA also takes into consideration these actors' own plans and projects, explicitly seeking 
to incentivize developers by linking infrastructure development to increases in the values of their large landholdings (NEDA, 2014: 35):

A preliminary survey conducted in this study indicates that there are a number of large scale privately owned properties located along the north-south direction well within the areas of Bulacan, Laguna and Cavite i.e., along the north-south main transport corridors. If these properties are developed in integration with mass-transit, it is possible to meet the large demand in the most cost effective manner.

This strategy unfolds as if the state, cognizant of its impaired planning capabilities, is trying to steer urban development in directions that serve the interests both of state agendas of economic growth and private agendas of capital accumulation. It is this integration of state spatial planning with an agenda of large-scale development of privatized spaces linked by financialized infrastructure development that we characterize as the Philippine state's move from an agenda of the "privatization of planning" to one of the "planning of privatization."

What has this shift meant for the relational role of developers? The agenda of Mega Manila development is still emergent and evolving, but two major trends appear to be taking shape. First, the Philippine state's PPP push appears to be further strengthening the role of conglomerates whose primary activity was real estate development in the production of urban space. Such actors have quickly realized that synergies can be developed between the new infrastructure initiatives (particularly transportation) and real estate. Developers have long sought to coordinate land acquisitions with large infrastructure projects, either on their own or by forming large consortia with other conglomerates. This process has previously resulted in the construction of large-scale developments in and around Metro Manila: Eastwood, Filinvest City, SM Central Business Park, or UP-Ayala Technohub are prime examples. With the formulation of the Mega Manila Dream Plan, the state now also actively incentivizes infrastructure by integrating it with opportunities for property development (Table 2). Ayala Land has unsurprisingly emerged as a leader in this area, successfully bidding for a \pm 2 billion tolled road-link toward South Luzon Expressway (SLEX), which services one of its major real estate developments, NUVALI. ${ }^{4}$ Since then, the group has multiplied road projects, but has also been involved in rail mass-transportation through two joint ventures engaged in railway line extensions (Light Rail Manila Corporation) and masstransit payment solutions (AF Payments Inc.). Other examples include the Lopez Group (the historical primary shareholder of Meralco) or the Metro Pacific Investment Corporation (MPIC). The MPIC, a conglomerate listed in Manila and owned by the Hong Kong-based First Pacific Company Limited, is relatively advanced in its diversification into a broad range of infrastructure and property development roles. It now holds controlling stakes of Meralco, Maynilad, and with the new spate of infrastructure PPP is now involved in concession rights for several major transportation initiatives (including Light Rail Manila, NLEX, CAVITEX, CALAX). Its parent company controls Philippine Long Distance Telephone Company (PLDT).

Developers' investment in infrastructure provision can take several forms, some of which are not conventional PPP. For instance, SM Investments Corporation joined discussions around the funding of NAIA-X, an expressway linking the airport to several CBDs in Metro Manila, while not being part of the consortium bidding for the project. The company saw that the project was at a standstill because of a disparity between the bidding offer and the actual costs estimated after due diligence, and proposed to bridge the funding gap through the creation of an "Infrastructure Support Fund" (ISF), which offered a loan of up to US \$146 million, "with a 20-year maturity, 10-year grace and zero interest" (Baclagon, 2017). 

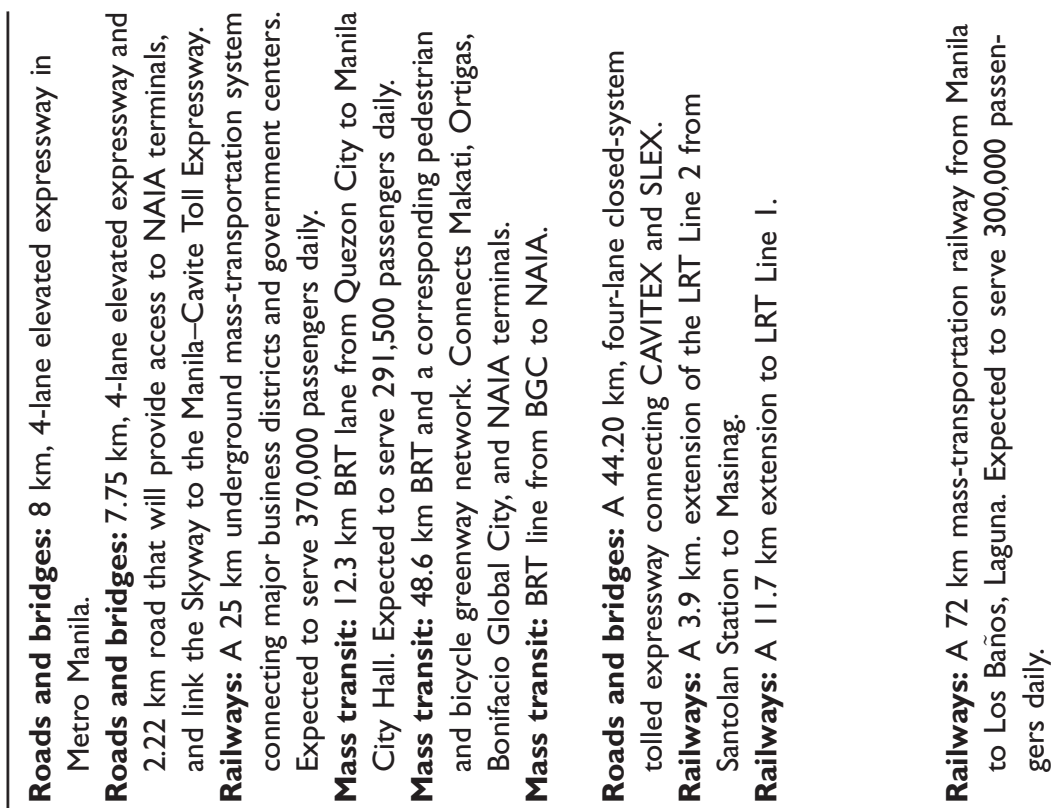

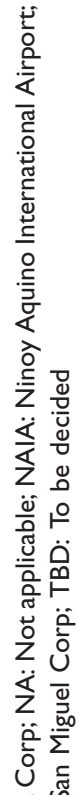

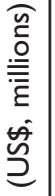

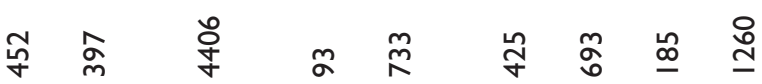


The condition was the construction of access ramps that would serve its Mall of Asia complex.

The second trend emerging with the state's infrastructure push is the diversification of large conglomerates previously not significantly involved in urban development into infrastructure and real estate. Notable here is SMC, the largest corporation in the Philippines, whose total sales in 2016 represented $4.7 \%$ of the country's entire GDP (SMC, 2017a). The company's origins can be traced back to 1890, with the creation of a brewery that quickly expanded internationally and later entered the food and packaging sectors. In the aftermath of the 2007 global financial crisis, the group began to diversify, and massively invested in infrastructure projects. After acquiring the oil refining company Petron in 2009, SMC invested in power production (SMC Global Power Holdings Corporation, San Miguel Energy Corporation) and in transportation. The group is now at the center of the wider metropolitan region's development projects, with stakes in highways (TPLEX, SLEX, Skyway stages 1 to 4, and NAIA-X), railed transportation (MRT-7), and the Manila North Harbor. As stated by the company's CEO, Eduardo Cojuangco (SMC, 2017b), SMC's traditional activities in food, beverages, and packaging put it in a strong position to engage in infrastructure development because they bring the cash flow the company needs to finance such initiatives (e.g. before toll roads are in operation and start generating revenues). SMC has also presented an unsolicited bid for a new airport in Bulacan that is intended to replace the current main facility in Metro Manila, which represents a clear effort to integrate infrastructure with property development. An SMC presentation to the Department of Transportation in early 2017 described an aerotropolis development over 2500 hectares of land, with more than half of that area set aside for a major urban development (Camus, 2017).

This new market for infrastructure investment raises two questions which merit further consideration and could inform future research on the political economy of urban production in Metro Manila. A first interrogation relates to the role of foreign investors. These actors have taken note of the infrastructure push, as evinced by the creation in 2012 of a US \$625 million private equity fund, the Philippine Investment Alliance for Infrastructure, run by a subsidiary of the Macquarie Bank, a prominent actor in this sector (Lorrain, 2010). ${ }^{5}$ What is their impact on Mega Manila's development, in the context of a country whose constitution imposes strict restrictions regarding foreign land ownership? A second avenue for future research would be to look more closely at the impact of the changes we described within the real estate sector itself. Which actors are the most able to profit from this agenda, and which are the ones left behind?

\section{Taking a direct stake in market-driven development: The rise of the Bases Conversion Development Authority}

Another way through which the Philippine state is trying to influence urban development is more circumstantial, but nonetheless reveals a salient inflection of the wider metropolitan region's planning history; it relates to the role of the Bases Conversion and Development Authority (BCDA), an agency that answers directly to the president of the Philippines. The BCDA represents one of the only tools for the state to directly intervene in urban development, through the mobilization of one of its last assets: the large tracts of military land inherited from the American colonial and postcolonial presence. This form of public intervention once again relies heavily on real estate developers and follows objectives of profitability (with some of the revenue being channeled toward the Philippine army). 
The BCDA is not a new agency, but it has acquired more leverage and has scaled up its projects. It was created in 1992 with the Republic Act 7227, and had the objective of transforming former American military bases into industrial and real estate developments - "productive civilian use" is the term employed in section 2 of the Act. While it had no financial resources at its creation, the organization was given important legal tools. It can purchase and manage land, exercise a right of eminent domain, and grant its developments the status of special economic zones. It therefore exerts near-complete control over its sizeable land bank of 41,000 ha. Its operations in and around Metro Manila include Bonifacio Global City (BGC), a brand new CBD spanning over 214 ha; Newport City, a leisure-oriented development adjacent to the Ninoy Aquino Airport; and the upcoming New Clark City, a "smart and green" city built from scratch on 9450 ha of land north of Metro Manila.

In a context in which land ownership is largely concentrated in the hands of the country's elites, the former military bases constitute a precious resource for the state, an opportunity for public authorities to bring forward their own plans for the mega-region. Interestingly, however, the BCDA's modus operandi in project development is to seek private partners to form a joint venture - the private side owning $55 \%$ of the formed entity and BCDA owning $45 \%$. Forming a joint venture with a private partner (Metro Pacific and then Ayala Land for BGC, Filinvest for New Clark City) is an unusual form of PPP, but it allows the agency to maintain oversight and control over the projects. The asymmetry of information that typically puts the public party at a disadvantage is therefore greatly reduced, and the BCDA remains involved throughout the entirety of project development.

With this organization, the state therefore extends its effort to harness the capabilities of private real estate actors. Such an attempt is not entirely disconnected from the wider effort to organize development in Mega Manila: The BCDA is also a major driver of the "infrastructural turn" of the Duterte administration. Its capacity to "construct, own, lease, operate and maintain public utilities as well as infrastructure facilities" (RA 7227, section 5) paved the way to an expansion of the scope of its action, and now places it at the center of the state strategy to structure urban development in the Mega Manila region. The BCDA recently completed a first transportation project - the Bus Rapid Transit line between the Ninoy Aquino Airport and BGC - and other ongoing ones include the expansion of the Clark International Airport as well as the Subic Clark Cargo Railway.

\section{Conclusion}

This paper has argued that real estate developers constitute a relevant object of analysis for exploring the conjuncture between forces operating at different scales in the production of urban space. The nature of their activity requires them to be "relational actors" that are able to mobilize numerous resources and interact with a myriad of institutions and organizations in order to materialize their projects. By retracing the trajectory of developers in the wider Philippine capital region, particularly in the last decade, we have tried to walk on a ridge line that gives us perspective over, on the one hand, macroeconomic transformations and the global circulation of urban models, and on the other hand, the local contingencies of the Philippine political economy. In other words, real estate developers offer a window into an analysis of "the interplay between grounded circumstances, mediating conditions and contingent effects" and "their enabling conditions of existence, operational parameters and connective circuits" (Peck, 2017: 9).

Adopting this approach proves to be a heuristic way of analyzing real estate production, which forces us to go beyond the oversimplification of ready-made narratives. The story we 
unfolded brings nuance to the main interpretative framework that one would tend to summon-perhaps too promptly or without enough hindsight - in order to shed light on the processes of urban production in and around Metro Manila: a process of state withdrawal in line with neoliberalizing forces at work at the global scale. It is indeed striking that corporate actors have seized numerous prerogatives that typically fall under the realm of the public sector (e.g. planning and building entire "chunks of city" with near-complete autonomy), and that privatization of service provision could hardly be more advanced. However, by focusing on the role of real estate developers and by studying their relationship to the state, a more complex picture emerges. Here, PPP certainly point toward a greater involvement of private actors in urban production, but they do not represent the desertion of the state from any attempt to steer metropolitan expansion. On the contrary, they appear as a way for a state that has little control over land to exercise an influence over the process of urbanization. As a consequence, with its current "infrastructural push," the Duterte administration is not only encouraging private investment, but also reasserting its control over urban development at the regional scale, in a movement that we characterize as a "planning of privatization."

\section{Acknowledgments}

The authors would like to thank the anonymous reviewers for their helpful comments on this paper, as well as the guest editors of this issue - and Sian Butcher deserves special mention for her valuable input. This article was enriched by numerous discussions with researchers from Ateneo de Manila's Department of Sociology and Anthropology, and benefited from fruitful interactions with Dominique Lorrain and Alvaro Artigas.

\section{Declaration of conflicting interests}

The author(s) declared no potential conflicts of interest with respect to the research, authorship, and/or publication of this article.

\section{Funding}

The author(s) disclosed receipt of the following financial support for the research, authorship and/or publication of this article: Fieldwork for this research benefitted from funding from the Université Sorbonne Paris Cité (USPC)-National University of Singapore (NUS) research project "GREENUT" and through the Ecole Nationale des Ponts et Chaussées (ENPC) "Cities" research chair.

\section{ORCID iD}

Morgan Mouton (D) http://orcid.org/0000-0002-3324-4808

\section{Notes}

1. Excerpt from an interview with Thomas Mirasol, head of the international sales division at Ayala Land, Inc. The interview was originally published in the Singaporean Business Times in May 2014, and then quoted in an article of The Philippine Star (June 20, 2014).

2. Demand for residential real estate has been largely driven by "overseas foreign workers," whose remittances account for a substantial share (over 10\%) of GDP, and who are targeted extensively by real estate developers offering condominium units or gated suburban developments (see, for instance, Ortega 2016). More recently, the business process outsourcing sector has also been a major driver for real estate development (Kleibert, 2015).

3. Vince Dizon, president and CEO of the BCDA. Extracted from the "Build build build" press briefing, ASEAN 2017 (International Media Center in Conrad Hotel on April 27, 2017). 
4. Ayala Corp. president and chief operating officer, Fernando Zobel de Ayala, explicitly said in an interview that: "This road project provides significant opportunities for synergies within the Ayala group, especially [their] real estate group, Ayala Land, as it cuts travel time to [their] residential and commercial projects in this rapidly growing part of the metropolis." The Inquirer, December 16, 2011, "Ayala bags 1st PPP road project."

5. Macquarie also owns $10 \%$ of the Light Rail Transit 1 (LRT 1) Cavite Extension, alongside Metro Pacific Investment Corp. (55\%) and Ayala Corp. (35\%). See the World Bank page for more details: http://ppi.worldbank.org/snapshots/project/light-rail-transit-1-(lrt-1)-cavite-extension-8727.

\section{References}

Aboitiz Group (2017) Annual Report 2016. Taguig City: Aboitiz Group.

Alcazaren P (2013) Metro Manila's urban chaos: What now? Ateneo de Manila University. Available at: http://www.ateneo.edu/lopezcmc/video/metro-manilas-urban-chaos-what-now (accessed 18 March 2019).

Ana FS (1998) Privatization and government reform in the Philippines. International Journal of Urban Sciences 2: 160-170.

ASEAN (2016) ASEAN investment report 2016: Foreign direct investment and MSME linkages. Report, Jakarta: ASEAN Secretariat.

Ayala Corporation (2017) Annual Report 2016. Makati City: Ayala Corp.

Baclagon L (2017) Creative transactions: The Philippines NAIA expressway project. World Bank Group: Infrastructure and public-private partnerships. Available at: https://blogs.worldbank. org/ppps/creative-transactions-philippines-naia-expressway-project (accessed 5 November 2017).

Bello W (2005) The Anti-Development State: The Political Economy of Permanent Crisis in the Philippines. London: Zed Books.

Bello W, Cardenas K, Cruz JP, et al. (2014) State of Fragmentation: The Philippines in Transition. London: Focus on the Global South and Friedrich Ebert Stiftung.

Brenner N and Schmid C (2015) Towards a new epistemology of the urban?. City 19(2-3): 151-182.

Brenner N, Madden D, and Wachsmuth D (2011) Assemblage urbanism and the challenges of critical urban theory. City 15(2): 225-240.

Camus M (2017) DOTr reviews San Miguel's P700 Bulacan airport. Philippine Daily Inquirer, Business/Corporate Online Edition, 15 February. http://business.inquirer.net/224608/dotrreviews-san-miguels-p700b-bulacan-airport\#ixzz4xJjTNrjf.

Caoili MA (1989) The Origins of Metropolitan Manila: A Political and Social Analysis. Quezon City: Cellar Book Shop.

Carballo M (2017) Debt-to-GDP ratio to drop by 2022. The Manila Times Online Edition, 15 July. http://www.manilatimes.net/debt-gdp-ratio-drop-2022-dbm/338472.

CBRE (2017) Investment Market Headwinds: Strengthening or Easing? The Property Perspective Global Capital Markets Report, June 2017. Los Angeles: CBRE.

Corpuz AG (2000) Integrating transportation and land use planning: The Metro Manila experience. In: Yabes R and Chifos C (eds) Southeast Asian Urban Environments: Structured and Spontaneous. Tempe: Arizona State University Program for Southeast Asian Studies Monograph Series Press.

DMCI (2017) Annual Report 2016. Makati City: DMCI.

Ernst and Young (2015) Riding the silk road: China sees outbound investment boom. Report, Ernst and Young, March.

Fainstein S (1995) Politics, economics, and planning: Why urban regimes matter. Planning Theory 14: 34-41.

Fainstein S (2001) The City Builders: Property Development in New York and London, 1980-2000. Lawrence: University of Kansas Press.

Filinvest Development Corp. (2017) Annual Report 2016. Taguig City: Filinvest Development Corp. First Philippines Holdings (2017) Annual Report 2016. Pasig City: First Philippines Holdings.

Freedom of Information Philippines (2017) Build build build: Philippine infrastructure transparency portal. Available at: http://www.build.gov.ph (accessed 2 November 2017). 
Garrido M (2013) The ideology of the dual city: The modernist ethic in the corporate development of Makati City, Metro Manila. International Journal of Urban and Regional Research 37: 165-185.

Harms E (2016) Luxury and Rubble: Civility and Dispossession in the New Saigon. Berkeley: University of California Press.

Hart G (2016) Relational comparison revisited: Marxist postcolonial geographies in practice. Progress in Human Geography 42(3): 371-394.

Hsing Y (2010) The Great Urban Transformation: Politics of Land and Property in China. Oxford: Oxford University Press.

Hutchcroft PD and Rocamora J (2003) Strong demands and weak institutions: The origins and evolution of the democratic deficit in the Philippines. Journal of East Asian Studies 3: 259-292.

IBON (2005) Water Privatization: Corporate Control versus People's Control. Manila: IBON Books.

JG Summit Holdings Inc. (2017) Annual Report 2016. Pasig City: JG Summit Holdings Inc.

Kang DC (2002) Crony Capitalism: Corruption and Development in South Korea and the Philippines. Cambridge, UK: Cambridge University Press.

Kelly P (2013) Production networks, place and development: Thinking through global production networks in Cavite, Philippines. Geoforum 44(Supplement C): 82-92.

Kleibert J (2015) Islands of globalisation: Offshore services and the changing spatial divisions of labour. Environment and Planning A 47(2015): 884-902.

Laquian AA, Ruble BA, Stren RE, et al. (2002) Metro Manila: People's participation and social inclusion in a city of villages. In Ruble BA, Stren RE, Tulchin JS, et al. (eds.) Urban Governance Around the World. Washington, DC: Woodrow Wilson Center Press and John Hopkins University Press, pp.74-110.

Leaf M (1993) Land rights for residential development in Jakarta, Indonesia: The colonial roots of contemporary urban dualism. International Journal of Urban and Regional Research 17(4): 477-491.

Leaf M (2015) Exporting Indonesian urbanism: Ciputra and the developmental vision of market modernism. South East Asia Research 23(2): 169-186.

Leitner H and Sheppard E (2015) Provincializing critical urban theory: Extending the ecosystem of possibilities. International Journal of Urban and Regional Research 40(1): 228-235.

Llanto GM (2004) Infrastructure Development: Experience and Policy Options for the Future. Makati City: Philippine Institute for Development Studies.

Llanto GM (2010) A Review of Build-Operate-Transfer for Infrastructure Development. Makati City: Philippine Institute for Development Studies.

Logan J and Molotch H (1987) Urban Fortunes: The Political Economy of Place. Berkeley: University of California Press.

Lorrain D (2010) Macquarie: Une banque dans les infrastructures. Flux: 81 67-78.

Lorrain D (2016) Les Conglomérats Familiaux (3). Suharto \& Co. Flux 105: 62-77.

Lorrain D and Mouton M (2017) Les Conglomérats Familiaux (5). Ayala Corporation. Flux 107: 91-103.

McCoy A (2009) An Anarchy of Families: State and Family in the Philippines. Madison: University of Wisconsin Press.

Megaworld Corp. (2017) Annual Report 2016. Taguig City: Megaworld Corp.

Mouton M (2015) The Philippine electricity sector reform and the urban question: How metro Manila's utility is tackling urban poverty. Energy Policy 78: 225-234.

MPIC (Metro Pacific Investment Corporation) (2017) Annual Report 2016. Makati City: MPIC.

NEDA (n.d.) Available at: www.neda.gov.ph/infrastructure-flagship-projects (accessed 18 March 2019).

NEDA (2014) Roadmap for transportation infrastructure development for Metro Manila and its surrounding areas (Region III and $I V$-A). Report produced in collaboration with the Japan International Cooperation Agency (JICA).

Ortega A (2016) Neoliberalizing Spaces in the Philippines: Suburbanization, Transnational Migration and Dispossession. Lanham: Lexington Books.

Peck J (2017) Transatlantic city, part 1: Conjunctural urbanism. Urban Studies 54(1): 4-30. 
Riedinger J (1995) The Philippines in 1994: Renewed growth and contested reforms. Asian Survey 35: 209-216.

Rithmire M (2015) Land Bargains and Chinese Capitalism: The Politics of Property Rights under Reform. Cambridge, UK: Cambridge University Press.

Robinson J and Roy A (2016) Debate on global urbanisms and the nature of urban theory. International Journal of Urban and Regional Research 40(1): 181-186.

Rouanet H and Halbert L (2016) Leveraging finance capital: Urban change and self-empowerment of real estate developers in India. Urban Studies 53(7): 1401-1423.

Sajor E (2005) Professionalisation or hybridisation? Real estate brokers in Metro Cebu, the Philippines, during the boom of the 1990s. Urban Studies 42(8): 1321-1343.

Schuster S, Balbosa J, Tang C, et al. (2017) Scaling Up Infrastructure Investment in the Philippines: Role of Public-Private Partnership and Issues. Asian Development Bank Southeast Asia Working Paper Series 13. Mandaluyong City: ADB.

Scott AJ and Storper M (2015) The nature of cities: The scope and limits of urban theory. International Journal of Urban and Regional Research 39(1): 1-15.

Searle L (2010) Making space for capital: The production of global landscapes in contemporary India. PhD Thesis, University of Pennsylvania, USA.

Searle L (2014) Conflict and commensuration: Contested market making in India's private real estate development sector. International Journal of Urban and Regional Research 38(1): 60-78.

Shatkin G (2005) Colonial capital, modernist capital, global capital: The changing political symbolism of urban space in Metro Manila, the Philippines. Pacific Affairs 78: 577-600.

Shatkin $\mathrm{G}$ (2008) The city and the bottom line: Urban megaprojects and the privatization of planning in Southeast Asia. Environment and Planning A 40(2): 383-401.

Shatkin G (2014) Reconsidering the meaning of the Singapore model: State capitalism and urban planning. International Journal of Urban and Regional Research 38(1): 116-137.

SMC (San Miguel Corporation) (2017a) Annual report. Makati City: San Miguel Corporation.

SMC (San Miguel Corporation) (2017b) SEC form 17-A. San Miguel Corporation.

SMIC (SM Investments Corporation) (2017) Annual Report 2016. Pasay City: SM Investments Corp.

Teehankee J (2016) The Philippines in 2015: The calm before the political storm. The Philippine Political Science Journal 37(3): 228-238.

van den Muijzenberg O and van Naerssen T (2005) Metro Manila: Designers or directors of urban development? In: Nas PJM (ed.) Directors of Urban Change in Asia. London: Routledge, pp. $126-147$.

Winarso H (2000) Residential land developers behavior in Jabotabek, Indonesia. PhD Thesis, University College London, UK.

Winarso H and Firman T (2002) Residential land development in Jabotabek, Indonesia: Triggering economic crisis? Habitat International 26: 487-506. 